\title{
IAMJ
}

INTERNATIONAL

AYURVEDIC

MEDICAL JOURNAL

ISSN: 2320-5091

Impact Factor: 6.719

\section{A COMPARATIVE CLINICAL STUDY FOR THE EVALUATION OF SNUHI KSHEERA-HARIDRA CHOORNA LEPA AND DEVADALYADI LEPA IN ARSHAS $\left(2^{\text {ND }}\right.$ DEGREE HAEMORRHOID}

\author{
Karthika K. L' ${ }^{1}$ Manjunatha Bhat ${ }^{2}$ \\ ${ }^{1}$ PG Scholar, Department of PG Studies in Shalya Tantra, Alvas Ayurveda Medical College, Moodbidiri, \\ Dakshina Kannada, Karnataka, India \\ ${ }^{2}$ Professor and HOD, Department of PG studies in Shalyatantra, Alvas Ayurveda medical College, Moodbidiri, \\ Dakshina Kannada, Karnataka
}

Corresponding Author: karthika.siva.4.kkl@gmail.com

\section{https://doi.org/10.46607/iamj0609112021}

(Published Online: November 2021)

Open Access

(C) International Ayurvedic Medical Journal, India

Article Received: 08/10//2021 - Peer Reviewed: 27/10/2021 - Accepted for Publication: 31/10/2021

\section{Check for updates}

\begin{abstract}
Today Ano-rectal diseases have emerged as a quite common occurrence with progressive nature. According to the Ayurvedic concept, the aetiology of Arsha is interconnected with Mandagni of the patients. Arsha is a kind of disease that is most unkind towards mankind. A few important causes are sedentary lifestyle, irregular bowel habit, low fibre diet, prolonged straining, sedentary job, suppression of natural urges is some of the causative factors at present. It is a Mamsakeela that obstructs the Gudamarga and thus tortures the patient like an enemy. It can be co-related to haemorrhoids in modern science, the most common ailments of the rectum and anal canal. Intermittent symbolization and embarrassment make people neglect the early stages of haemorrhoids and ultimately end up in complications. The four therapeutic measures of Arshas include Bheshaja chikistha, Shastra karma, Kshara karma, and Agnikarma. Lepa is the foremost effective Bheshaja Chikistha yet less practised and demands further exploration. So based on Arsha Adhyaya of Susrutha Samhita and Arshoghnaadhyaya of Rasa ratnasamucchaya, the present study is intended to evaluate Snuhi ksheera - Haridra Choorna Lepa and Devadalyadi lepa in Arshas.
\end{abstract}


Keywords: Haemorrhoids, Arshas, Snuhi Ksheera- Haridra Choorna Lepa, Devadalyadi Lepa

\section{INTRODUCTION}

"अरिवत्प्राणिनो मांसकीलका विशसन्ति यत्| अर्शांसि तस्मादुच्यन्ते गुदमार्ग निरोधतः " 1

Arsha is one among the Mahagada ${ }^{2}$ which obstructs the Guda marga and tortures the patient like an enemy. Arsha can be correlated to Haemorrhoids. Haemorrhoids are quite common in society. Haemorrhoids are symptomatic anal cushions with symptoms like bleeding, mucous discharge, prolapse and pain. ${ }^{3}$ Arsha incidence increases with advancing age, at least $50 \%$ of people over the age of 50 years have some degree of haemorrhoidal symptoms. In 2000, the incidence of internal haemorrhoids was $72 \%$. Recent statistics reveal that irrespective of age, sex, socio-economic status, people suffer from haemorrhoids. ${ }^{4}$ Modern medicine offers treatments like sclerotherapy, infrared photocoagulation, rubber band ligation, cryosurgery, anal dilatation, and various other topical ointments. But the options are limited in concern with their recurrence. ${ }^{5} \mathrm{In}$ Ayurveda treatise, treatments like Bheshaja karma, Kshara karma, Agni karma, Shastra karma, Rakthamokshana are advised. The importance of Lepa arises in the case of those, who can't bear the pain or are not fit for the surgery. This procedure can be done easily and is cost-effective. In Arsha Chikitsa Lepa is the first and foremost effective Bheshaja chikitsa explained, yet less practised and demands further exploration. Snuhi ksheera - Haridra Choorna Lepa is mentioned in Arsha Adhyaya of Susrutha samhitha ${ }^{6}$ and Devadalyadi Lepa in Arshoghna Adhyaya of Rasa Ratna samucchaya. ${ }^{7}$ Devadali, Snuhi and Haridra have common properties like Katu rasa, Laghu Guna, Katu Vipaka and Ushna veerya. ${ }^{8}$ In the light of the above-mentioned disease prevalence and its treatment modality, here an attempt was made to compare the effect of Snuhi ksheera-Haridra Choorna Lepa and Devadalyadi Lepa in the management of Arsha.

\section{MATERIALS AND METHOD * SAMPLE SOURCE}

40 Patients who attended the OPD and IPD of the Shalya Tantra department, Alva's Ayurveda Medical College Hospital and from the camps and referrals were divided into Group A and Group B.

* Sample Size - 40 patients fulfilling diagnostic and inclusion criteria were selected and assigned randomly into two equal groups Group A and Group B

* Study Design - Comparative Clinical Study DIAGNOSTIC CRITERIA

The diagnosis was based on two or more Classical features of Arshas as mentioned in classical texts like:

\section{$>$ Rakthasrava \\ $>$ Arsha bhramsha \\ $>$ Srava \\ $>$ Kandu \\ $>$ Gudavedana \\ $>$ Vibandha}

\section{PROCTOSCOPIC EXAMINATION}

$\checkmark$ Position.

$\checkmark$ Degree.

$\checkmark$ Several Haemorrhoidal masses were examined. INCLUSION CRITERIA

1) Both genders.

2) Age group between.

3) $16-70$ years $2^{\text {nd }}$ degree Haemorrhoids.

\section{EXCLUSION CRITERIA}

1) Haemorrhoids that are Thrombosed, Strangulated, Inflamed.

2) Haemorrhoids associated with Fissure in ano, Fistula in ano, Perianal abscess, Rectal polyps, Rectal Prolapse, Rectal ca.

3) Patients having Tb, DM, coagulopathies, HIV and HBsAg positive.

4) The patient has Ulcerative colitis, Crohn's disease.

5) Pregnant woman. 


\section{PROCEDURE FOR GROUP A AND GROUP B}

\section{* Group A}

Materials required: Snuhi ksheera, Haridra Choorna, Hareethaki choorna, Slit proctoscope, 2\% Lignocaine, Sterile gloves, Sterile gauze, Cotton pads and Surgical Spirit.

\section{* Group B}

Materials required: Devadalya beeja Choorna, Saindhava, Aranaala, Hareethaki choorna, Slit Proctoscope, 2\% Lignocaine, Sterile gloves, Sterile gauze, Cotton pads and Surgical spirit.

\section{Purva karma:}

1. Informed Consent of the patient was taken.

2. Preparation of the part was done.

\section{Pradhana karma:}

1. The patient was made to lie down in a Lithotomy position.

2. Anus and surrounding parts were cleaned with Povidone-iodine Lotion and Surgical Spirit

3. A slit proctoscope was introduced into the anal canal after lubricating it with $2 \%$ lignocaine jelly and then the obturator was removed. The visible haemorrhoidal mass which is protruded through the slit proctoscope was identified then the lepa was applied to the Arshas.

\section{Paschat karma:}

1. After 20 minutes of lepa the area was cleaned with distilled water.

2. Then the patient was made to lie down in a comfortable posture for 15 minutes.

3. Both groups were given $5 \mathrm{~g}$ of Hareethaki Choorna with lukewarm water orally at bedtime for 7 days.

\section{STUDY PERIOD}

Including observation and follow up -Total 60 days

\section{INTERVENTIONS}

Group A: Application of Snuhi ksheera - Haridra choorna Lepa once in a day was done and $5 \mathrm{~g}$ of Hareethaki Choorna was given along with lukewarm water at bedtime daily for 7 days.

Group B: Application of Devadalyadi Lepa once a day was done and $5 \mathrm{~g}$ of Hareethaki Choorna was given along with lukewarm water at bedtime daily for 7 days.
The assessment was done after the treatment on the 8th, 15th, 22nd and 29th days.

* Follow Up: The patient was reviewed on the $45^{\text {th }}$ and $60^{\text {th }}$ days.

\section{* Assessment Criteria}

A detailed proforma was prepared and assessment was done based on gradations given for the subjective and objective parameters and obtained data were analysed statistically with Wilcoxon rank test and chi-square test.

\section{Subjective Parameters:}

1. Bleeding per rectum

2. Mucous discharge per anum

3. Pain

\section{Objective Parameters:}

1. Degree of haemorrhoidal mass

\section{* RESULTS}

The study was carried out in 40 patients of Arsha, 20 patients in each group, Group- A and Group- B, Both the group patients were given Hareetaki Choorna internally for 7 days. Group- A patients were treated with Snuhi Ksheera - Haridra Choorna Lepa and Group B were treated with Devadalaydi Lepa daily once for 7 days and Hareetaki Choorna with like warm water internally for 7 days.

Total patient registered for study: 40 Patient treated as Group- A: 20 Patient treated as Group- B: 20

Comparative analysis of the overall effect of the treatments in both groups was done statistically with the Mann Whitney test. The test shows that the treatment is highly statistically significant in Group A when compared to Group B. Group A overall result is $67.02 \%$ and Group B overall result is $90.50 \%$.

\section{DISCUSSION}

Age: Maximum percentage of $30 \%$ patients belonged to age group 16-25 years, $20 \%$ between 26 to 35 years and $22.5 \%$ patients were between 36 to 45 years, among 46 to 55 years is

$15 \%$ and between the age group of 56-65 and 65-70 have $10 \%, 2.5 \%$ each.

Gender: Among the total number of patients in this study, $67.5 \%$ of the patients where male was in $32.5 \%$ were females. This may be due to the nature of 
work and food habits among the males which contribute to the occurrence of the disease more in males than females.

Religion: The majority of the patients in this clinical trial were Hindus i.e., 90\%, Muslim community contributed $7.5 \%$ of the patients. And $2.5 \%$ belonged to the Christian religion. This shows the dominance of the Hindu population in this region where the study was carried out

Occupation: The distribution of the patients according to the occupation showed that about $27.5 \%$ of them were in office work, $25 \%$ were labourers and students, $12.5 \%$ were housewives and $10 \%$ were of business. Avoidance of the natural urges due to inevitable circumstances are the nature of some of the occupations which may influence the disease.

Diet: Most of the patients were of mixed diet contributing to $65 \%$ and vegetarians $35 \%$. This shows the incidence of the Arsha among the patients with mixed diet as their dietary habits included meat, fish, spices, fried and oily food items which is the cause.

Appetite: Among 40 patients $65 \%$ have reduced appetite. This gives a brief idea about the role of Mandagni according to Vagbhata and Susrutha, Mandagni is the causative factor of Arshas.

Bowel habits: A maximum of $67.5 \%$ was found to have constipated bowel habits and $32.5 \%$ have regular bowel habits. Chronic constipation can lead to Arshas. More straining for expelling constipated stools will lead to dilatation of the venous plexus.

Addictions: It shows most of the patients were addicted to one or the other thing during the study. Smoking, Alcohol, Betel and Tobacco chewing are $37.5 \%, 32.5 \%, 22.5 \%, 7.5 \%$ all these may cause Haemorrhoid in one or another way by impairing bowel habits and harming the blood vessels leading to engorgement of the anus.

Position of pile mass: In the case of the position of pile mass in the majority of patients in this study got from 11 o'clock position that is $37.5 \%, 35 \%$ from 7 o'clock position and $27.5 \%$ are of 7 o'clock position. The reason is clear rectum is supplied by middle, inferior and superior rectal veins corresponding to 3, 7 and 11 o'clock positions. Dilatations of rectal venous plexus due to excess pressure over blood vessels during straining are called Haemorrhoids.

Presenting Symptoms: Symptoms like Bleeding per anum, Mucous discharge, Pain and Mass per anum were noticed as $47.5 \%, 15 \%, 15.5 \%, 22 \%$ of patients respectively.

\section{MASS P/A (DEG REE OF THE HAEMORRHOIDS)}

It is dependent on the extent of the mass as well as the reducibility of the mass. Straining during defecation, hard stools are the causes of the mass. In Group A 60\% is seen and in Group B after the treatment with $72.50 \%$ improvement is seen.

\section{BLEEDING PER ANUM}

Bleeding is one of the major symptoms of Arsha. In Group A, only $62.96 \%$ is seen and in group B $100 \%$ relief is seen. It is due to Rakta Stambhaka and Sophahara property of the Lepa. Stoppage of bleeding is due to Rakthasthambhaka and Vrana Shodhana property of Lepas. Snuhi Ksheera-Hridra choorna lepa

\section{PAIN}

Pain is not a common symptom in $2^{\text {nd }}$ degree Haemorrhoid as commonly it is situated above the dentate line. But in chronic cases because of congestion and some amount of prolapse and friction of constipated hard faecal matter, most of the patients feel some discomfort and pain. In group A $74.26 \%$ got relief and in group B $95.24 \%$ got relief. Lepa reduces congestion, size of mass along with Hareethaki Choorna. Both Lepa has Shodhahara, Shoolaghna and Arsoghna properties. Therefore, it can be concluded that the Lepa is highly effective in the reduction of pain.

\section{MUCOUS DISCHARGE PER ANUM}

Mucous discharges are mostly seen in Arshas associated with itching. Hereafter treatment in Group B 100\% got relief and Group A 56.25\%

\section{PROBABLE MODE OF ACTION OF SNUHI KSHEERA-HARIDRA CHOORNA LEPA}

Haridra is having Ushna, Teekshna, Shothahara, Vranaropana, Rakta Shodhaka, Rakta Stambhaka, Kapha-Vata hara properties. Snuhi Ksheera is also having Katu, Tiktha Rasa, Laghu-Ruksha Guna, 
Ushna Veerya, Katu Vipaka. Haridra contains Demethoxycurcumin, Curcumin, Zingiberin etc which have a haemostatic and anti-inflammatory effect. Chemical cauterization and corrosive nature of Snuhi Ksheera with a $\mathrm{pH}$ of 5.2 help in reduction in the size of the mass of haemorrhoids. So, the Lepa improves blood circulation to the part. There is a reduction in the size of the Haemorrhoidal Mass.

\section{PROBABLE MODE OF ACTION OF DEVADALYADI LEP}

Devadali has properties like Katu rasa, Laghu guna, Katu vipaka and Ushna veerya. Aranala is having Amla rasa, Laghu teekshna- snigdha guna, Ushna veerya, Amla vipaka. Saindhava is having Lavana and Madhura Rasa, Snigdha-Teekshna-Guna, Sheetha Veerya. So, the combination of these three can improve reduction in mass of haemorrhoid, pain to an extent and bleeding per anum. The juice of seedlings of luffa echinata exhibited mild antifungal activity. The active constituent of Luffa echinata includes Sapogenin, Cucurbitain B\&E, Gyprogenin, Saporins, Chrysoeriol, Glucoside etc in which cucurbitain have an anti-inflammatory property. Chrysoeriol a flavinoid have antioxidant, antiinflammatory, anti-thrombogenic properties. These properties of luffa echinata help in the reduction of haemorrhoidal size.

\section{CONCLUSION}

The following useful conclusion was drawn based on the review of literature and observations made in this clinical study with 40 patients of Arshas were taken for clinical study which was divided into 2 groups of 20 patients. The two groups were studied in detail after with Group A Sunhi Ksheera -Haridra Choorna Lepa and Group B Devadalyadi Lepa. Arsha effect a large number of populations. Arsha is a disease of Chirakala Anubhandhithwam. It is the foremost common disease among Ano-rectal disorders and the area of concern ever since the Vedic periods. Its incidence is due to frequent straining (due to constipation) and some of the other factors associated with the formation of Haemorrhoids, low fibre diet, sedentary lifestyle, standing or sitting for long extended periods, lack of exercise. The symptoms of Arshas were found to be congruent with the clinical picture of Haemorrhoids. The present study suggests a greater number of patients were from the age group of above 16 to 45 years, it is observed their sedentary lifestyle, junk foods and hotel foods, lack of exercise, stressful life in studying and working area leads them to the formation of Haemorrhoids. In this clinical study, males are more prone to Haemorrhoids may be more males who came during the study, or a greater number of patients was having a sedentary lifestyle which resulted in constipated bowel. It has been observed that a greater number of patients have Ardra Arshas in both Group A and Group B. Both groups showed highly satisfactory results in all the presenting signs and symptoms. On comparing the effect of treatment between two groups i.e., Group A and Group B. Trial Group showed a statistically result. Group B have a better result than Group A. So, we conclude that Devadalyadi Lepa is having better result than Snuhi Ksheera- Haridrsa Choorna Lepa in the management of Arshas ( $2^{\text {nd }}$ degree haemorrhoids). Thus, an alternate hypothesis is accepted. Therefore, by observing the above data null hypothesis is rejected and the alternate hypothesis (H2) is accepted.

\section{REFERENCES}

1. Acharya Vagbhata, Ashtanga Hridaya, Pandit Hari Sadasiva Pardakara Bhishagacarya, Chaukamba Surabharati Prakashan, $6^{\text {th }}$ Edition, $7^{\text {th }}$ Chapter, Sloka 3, Page 490

2. Acharya Susrutha, Susrutha samhita, translator prof K.R srikantha murthy (rtd) principal, Chaukamba Orientalia, Varanasi, $33^{\text {rd }}$ Chapter Sloka 4-5, Page 233.

3. Bailey and Love's Short Practise of Surgery, edited by Norman S Williams, Christopher J.K Bulstrode and P Ronan O'Connell $25^{\text {th }}$ Edition, $6^{\text {th }}$ Chapter, P1074.

4. Www.Omicsonline.Org/India/Haemorrhoids-PeerReviewed-Pdf-Ppt articles.

5. Dr Somen. Das, A Concise Textbook of Surgery, $6^{\text {th }}$ Edition, Published

6. By Dr.S. Das, Kolkata, $45^{\text {th }}$ Chapter, Page 1074.

7. Acharya Sushrutha, Sushrutha Samhita, chikistha Sthana, edited and translated by Priyavrath sharma, 
Chaukamba orientalia, publications, Reprinted 2005,

Sloka No 12, Page 333

8. Acharya vagbhata, rasaratna samucchaya by acharya sidhntha Mishra, chaukamba orientaliya, published in $2011,25^{\text {th }}$ chapter Sloga 82 , page 355

\section{COMPARATIVE RESULTS OF GROUP-A AND GROUP-B}

\section{Table1}

\begin{tabular}{|l|l|l|l|l|l|l|}
\hline Symptoms & Group A (Mean Score) & Group B (Mean Core) & S.D $( \pm)$ & S.E ( \pm ) & T VALUE & P-VALUE \\
\hline Bleeding Per Anum & 0.58 & 0.49 & 0.380 & 0.071 & 0.85 & $<0.001$ \\
\hline Mucuos Discharge Per Anum & 0.39 & 0.25 & 0.242 & 0.045 & 2.06 & $<0.001$ \\
\hline Pain & 1.07 & .83 & 0.646 & 0.120 & 1.22 & $<0.001$ \\
\hline Degree Of Mass Per Anum & 1.09 & 1.12 & 0.541 & 0.100 & 0.24 & $<0.001$ \\
\hline
\end{tabular}

Table 2

\begin{tabular}{|l|l|l|l|l|l|}
\hline GROUP A & GROUP B & MEAN DIFFERENCE & SE $( \pm)$ & T VALUE & P-VALUE \\
\hline 67.02 & 90.50 & 23.48 & 4.67 & 4.53 & $<0.001$ \\
\hline
\end{tabular}

\section{Graph 1}

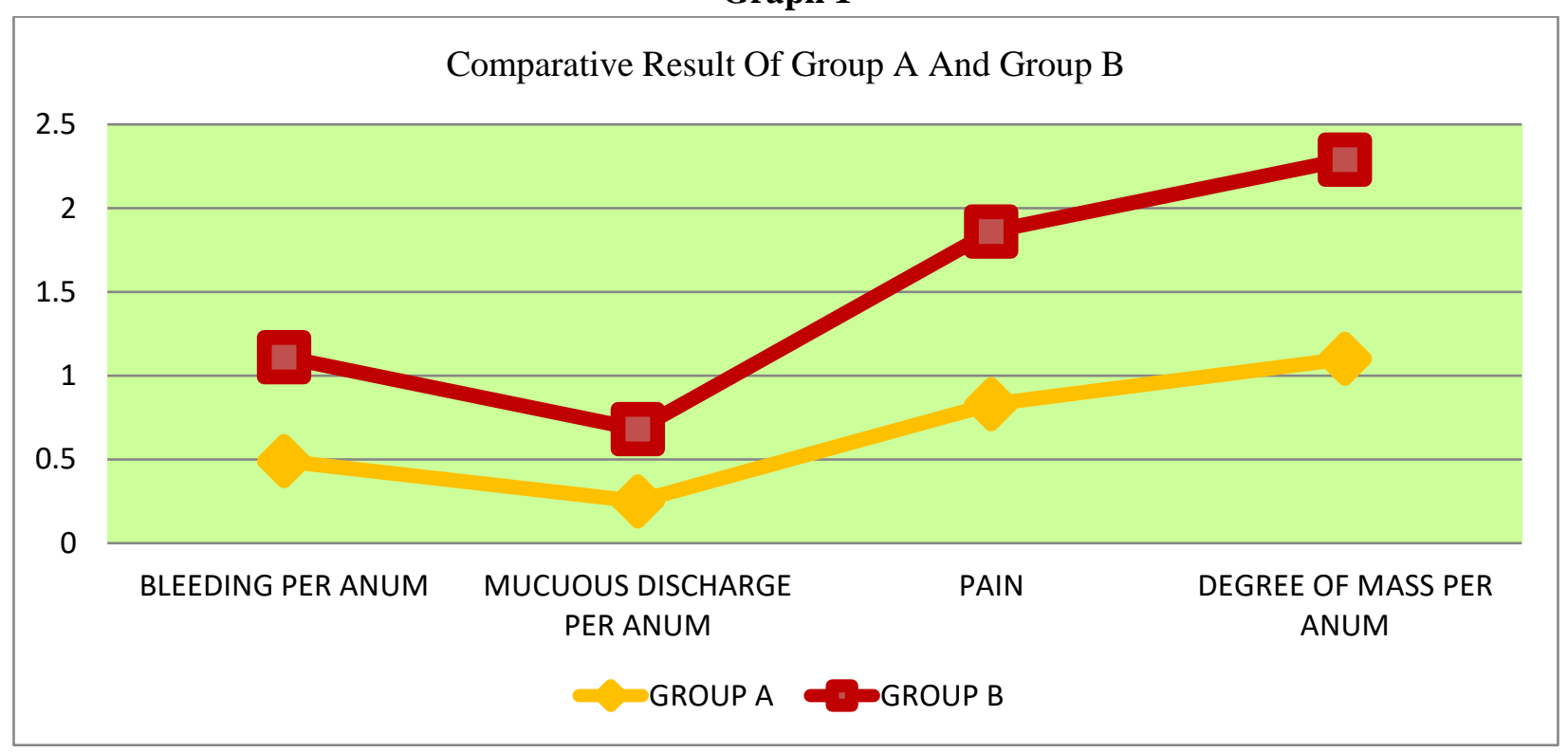

\section{Source of Support: Nil}

\section{Conflict of Interest: None Declared}

How to cite this URL: Karthika $\mathcal{K}, \mathcal{L}$ Q $\mathcal{L}$ Manjunatha Bhat: A Comparative Clinical Study For The Evaluation Of Snufi KsheeraHaridra Choorna Lepa And Devadalyadi Lepa In Arshas (2nd Degree Haemorrhoid. International Ayurvedic Medical Journal \{online\} 2021 \{cited November 2021\} Available from: http://www.iamj.in/posts/images/upload/2678_2683.pdf 